\title{
A PREDICTIVE MODEL OF EXPRESSIVENESS BASED ON DEMOGRAPHIC AND SOCIO-ECONOMIC FACTORS OF THE INDIAN YOUTH: A SELF - PERCEPTION
}

\author{
Dr. Kajal Srivastava \\ Assistant Professor, Area of Business Communication \\ Jaipuria Institute of Management, Lucknow \\ Aditya Prabhakar \\ Student (PGDM) \\ Jaipuria Institute of Management, Lucknow
}

\begin{abstract}
The objective of this research is to identify various demographic and socio-economic factors which play a role in shaping the expressive behavior of an individual, based upon their self-perception. The research methodology comprises of aclose-ended questionnaire, which records not only the demographic and socioeconomic details but also, objectively quantifies the qualitative aspects of expressiveness in an individual. Results of 220 respondentswereanalyzed usingSPSS. Thereafter, a predictive model of expressiveness was created using Regression Analysis. Considering a significance level of $10 \%$, major findings indicate that factors like the education level, openness to the opposite gender, number of friends, family income, occupation of the mother, highest level of education attained by the father, and expression in front of a stranger are significant. Research implications suggest that schools and Institutes should design curriculums which encourage students to participate in team-building and other leadership activities in order to boost their expressiveness.
\end{abstract}

Keywords: Expressiveness, Demographic Factors, Self-Perception, Education level, Predictive Model

\section{INTRODUCTION}

The world today has multiple avenues for millennials and generation $\mathrm{Z}$ in terms of job prospects. There are diverse fields that an individual can explore. Among the host of opportunities prevalent in the current scenario, the youth today is oriented towards finding jobs in the technical, administrative and sales sectors, which is different from the earlier trend where the thrust was more towards finding jobs related to sectors in managerial, executive and professionally specialized areas (Ryscavage, P., 1993). Nevertheless, no matter what the preferred job sector might be, the fact remains that employees hired by organizations are sought on the basis oftheir personality, the knowledge that they carry in a particular domain, interpersonal skills and soft skills.

The objective of companies is to hire employees who are adept at improving workforce productivity, which in turn, would naturally increase productivity in the company (Winkler, S., König, C., \& Kleinmann, M., 2013). In addition to this, with changes in both the nature of work and the workplace, employers today have new expectations from their employees (Morris M and Massie P., 1999). Resultantly, cognitive skills are highly valued considering the everchanging nature of jobs. Furthermore, with the latest buzzword being "sustainability," it is imperative that employees today are flexible and adept in their attitudes. Employees being sought out need to be able to learn rapidly and possess good generic skills (Maclean and Ordonez, 2007). Companies seek individuals who would be employable for longer durations to ensure stability within the organization. This further implies that if one wants to be employable, an individual should be responsive to changing demands in the industry in terms of skill sets required for a particular job (Sanders \& De Grip, Fugate et al, 2004).

With a huge emphasis on soft skills, there lies even a greater thrust on hiring employees according to their personality profile, depending on the nature of their respective jobs. For example, it would be ideal to hire extroverts, especially if the job entails interactions with the outside world. In an 
interview on Radio's Employability Mix, the General Manager, George Fiacchi stated that on-air personalities are generally more extroverted as compared to the administration staff who are introverted (Advertiser, The Adelaide, $8^{\text {th }}$ December 2007). Extroverts have the ability to think fast and act accordingly. Other characteristics of an extrovert include being good at building networks, speaking while thinking, and generating ideas during conversations. They are good at team collaborations, generating ideas while talking and they simply adore attention given to them. It is stated that companies should prefer having face-to-face conversations with extroverts in order to collaborate on their views and ideas (Kahnweiler, J. B., 2011).

On the other hand, traits of introverts include thinking before speaking, knowing more than they project, and they happen to work well under little supervision. An interesting fact is that many researches publications state that the population is made up of $25 \%$ introverts (Edelberg, G. S., 2006).

Whether we consider traits of an extrovert or an introvert, there is a level of expressiveness involved in both. It may further be added that culture has a major role to play in individuals being either introverted or extroverted, thereby affecting their expressiveness. That is to say, low context cultures believe in open and frank communication which leads them towards extraversion. However, in high context cultures, where meaning is implied, people tend to be veered towards introversion. Nevertheless, any given culture displays fluidity between high and low contexts, depending upon the circumstances. Similarly, an individual also tends to display traits that can either be introvert or extrovert, subjectupon the circumstances. Depending upon various factors, an individual may be skewed more towards introversion or extraversion. Based on the same, it is interesting note the level of expressiveness in both cases and factors that affect it.

In current times, the role of media and social on-line platforms on the expressiveness of individuals cannot be denied. According to Mangla and Manisha (2019), media plays a strong role as far as social responsiblities of individuals are concerned. In another study by Arjun and Rai (2018), the concepts of online trolling, bullying, abuse and rampant social media trial are explored. Utpal (2017) traces the patterns of student engagement, usage and network patterns and routine activitieson Facebook. Quite clearly, social media and media also tend to affect the way individuals express themselves.

Based upon demographic and socio-economic factors, the various research questions framed to analyse expressiveness are as follows;

$\mathrm{RQ}_{1}$ : Does age of an Individual affect his/her expressive behavior?

$\mathrm{RQ}_{2}$ : Is one better able to express oneself in his/her mother tongue?

$\mathrm{RQ}_{3}$ : Does one's gender affect the expressive behavior of an individual?

$\mathrm{RQ}_{4}$ : Does the type of place one belongs to affect the expressive behavior of an individual?

$\mathrm{RQ}_{5}$ : Does the medium of Education affect the degree of expressiveness in a person?

$\mathrm{RQ}_{6}$ : Does Convent Education affect the expressive behavior of a person?

$\mathrm{RQ}_{7}$ : Does Family Composition affect the expressive behavior in an individual?

RQ8: Do the number of siblings affect the degree of expressiveness in a person?

$\mathrm{RQ}_{9}$ : Does the education level affect the level of expressiveness?

$R Q_{10}$ : Does openness to the opposite gender affect expressiveness?

$R Q$ 11: Do the number of friendsinfluence expressiveness?

$\mathrm{RQ}_{12:}$ Does family income affect expressiveness?

$\mathrm{RQ}_{13}$ : Does the education level of parents have an effect on expressiveness?

$R Q$ 14: Can articulating in front of a stranger have an impact on expressiveness?

Primarily, the objective is to analyse an individual's basic details, family details and level of expressivess with respect to the research questions framed above. Thereafter, based on the information provided, the research proposes a predidictive model of expressiveness based on self-perception.

\section{LITERATURE REVIEW}

Before coming to the term "expressiveness," it's imperative to understand the terms "introvert and extrovert" as well. The term "introvert," according to The Cambridge University has been defined as "someone who 
is shy, quiet, and prefers to spend time alone rather than often being with other people." On the other hand, the definition of an extrovert in the same dictionary has been stated as "an energetic person who enjoys being with other people: Most salespeople are extroverts."

Further definitions are as follows; "(1) Introvert: An individual in whom exists an exaggeration of the thought processes in relation to directly observable social behavior, with an accompanying tendency to withdraw from social contacts. (2) Extrovert: An individual in whom exists a diminution of the thought processes in relation to directly observable social behavior, with an accompanying tendency to make social contacts." (Wikipedia)

Similarly, the term "expressiveness," as defined in the Cambridge Dictionary is; "the state of showing what someone thinks or feels." According to Kozhina, expressiveness is a "speech structure, fulfilling the communication purposes and aims at attaining the highest degree of communication effectiveness" (Kozhina, 1987). Therfore, it can be said that expressiveness is a mode of communication which enhances utterance.

Tracing the history of introverts and extroverts, they were first introduced by Carl Jung, the Swiss psychiatrist. Jung has described an introvert as person who withdraws into oneself, especially during emotionally stressful and conflicting times. Another feature of an introvert is the tendency to be shy and to work in solitude. On the other hand, in stark comparison to the introvert, the extrovert seeks others' company during stressful times and is more sociable by nature. Hans Eysenck's research lists two main dimensions of personality which account for different traits among persons we come across; they are extroversion and introversion. Eysenck has described the characteristics of an introverted person as being unsociable, reserved, pessimistic, anxious and moody. On the other hand, the qualities of an extrovert are that one is sociable, optimistic, carefree and lively. (Eysenck and Eysenck, 1963).

There have been various researches which have attempted to explore the relationship between personality and the occupation that an individual opts for. According to Filer (1986), an individual's occupational prediction should not be based upon salary but on an individual's tastes and productive attributes. These productive attributes are inclusive of educational background, experience and personality trait which make certain individuals more suited for a particular job.

Career Needs Theory states that differences in occupation are caused by selective factors or pressures that an occupation wields upon the individual. Super and Crites have stressed upon the importance of understanding personality and its influence on an individual's vocational choice. According to them, "every individual has certain abilities, interests, personality traits, and other characteristics which, if he/she knows them and their potential value, will make him/her a happier man/woman, a more effective worker, and a more useful citizen." (Super and Crites, 1962)

There have been various other researches which have investigated factors affecting introversion and extraversion. According to Vidhu Mohan and Dalip Kumar (1976), their research on "The Qualitative Analysis of the Performance of Introverts and Extroverts on Standard Progressive Matrices" points towards the initial superiority of extroverts over introverts. Interestingly, the research further proved that with increased time duration and increased level of difficulty, introverts showed better performance.

Eysenck (1967) has clearly stated that difference in the intellect of an individual might be based upon personality dimensions of Extraversion/Introversion (E/I) and Neuroticism (N). Nevertheless, the relation between E/I and intelligence is found to be linear and negative (Lynn \& Gordon, 1961; Child, 1964; Madan, 1967; Eysenck, 1967). Resultantly, introverts opt for accuracy whereas, speed is opted for by extroverts. In addition to this, extraversion is significantly related to entrepreneurial potential ( $R$. Zeffane, 2013).

It is on the basis of personality traits that organizations today seek people who would fit into their culture and add value to it. Therefore, it is not just conceptual knowledge which is sought after but also interpersonal skills and passion for a given job profile. To get the perfect fit, as far as passion is 
concerned, companies should hire people on the basis of "Big Five" This is a statistical technique which began in 90's. It is based on factor analysis. These five factors have developed from careful "meta-analyses" (McCrae \& Costa., 2002) and have stood true to various cultures and countries. They are the universals of personality and they include; Extraversion vs. Introversion, Conscientiousness vs. Un-directedness, Agreeableness vs. Antagonism, Emotional Stability vs. Neuroticism and Openness vs. Closed to Experience

The big five are used majorly in professional development and testing. Based on the above, while an extrovert would want to work with others and social activities, an introvert would prefer sticking around in one corner and working alone in a quiet environment.

Further research conducted in this regard is with specific reference to social media. This is considering the fact that we live in a hypermediated world around us and that youth today is highly active on the social media. In fact, the manner in which introverts present themselves on-line is way different from extroverts. As it is, introverts present their "real-selves" online whereas extroverts present their "real-side" through traditional and social interaction (Mary Ann Liebert, Inc., 2002).

With such a close link between an individual's personality trait and job occupation, Management Institutes across the globe aim at identifying personalities of an individual and specifically counselling students on the jobs that they should take up in the future. The aim is to identify and match students on the basis of their personality profile to a job best suited for them. Resultantly, there are a host of electives which management institutes offer today to cater to a vista of opportunities in various industries across all sectors.

It cannot be denied that there is a direct link between the personality of the individual and his/her impact on the working style and his/ her performance. Interestingly, many researches establish a relation between the student and his/ her academic performance, choice of electives and that of career (Tett et al., 1991; and Singh, 1994). Therefore, an analysis of familial, demographic and socioeconomic factors which contribute to expressiveness in an individual can not only aid managerial students into the kind of job that they should opt for, but also give an insight to soft skill trainers, career counsellors and psychologists in selecting and adopting appropriate training techniques thereby facilitating students acquire the required skill sets for a specific job.

\section{OBJECTIVE OF RESEARCH}

The aim of this paper is to chalk out factors that influence expressiveness in the Indian youth of today with specific reference to the family, demographics and socioeconomics. The factors taken into account include the role of family, upbringing, education and expressiveness in terms of social media. The idea is to understand major contributors as far as expressiveness is concerned and predict a model for the same.

Since this paper explores the familial aspect and its effect on Indian youth as far as expressiveness is concerned, it would be ideal to understand the family composition of the Indian community. Indians, by far, have always been a people who have thrived in communities. The Indian society is one which is both collectivistic and interdependent (Chadda RK, Deb KS, 2013). In addition to this, it promotes social cohesion (Chadda RK, Deb KS, 2013). Collectivism has been defined as "a sense of harmony, interdependence and concern for others" (C. Hui and H. Triandis, 1985). Tracing back yesteryears, the concept, as far as families were concerned, used to be that of a joint one. The idea behind joint families was quite simple; a large group of people who belong to a similar bloodline, living together to give each other support and care. India is majorly a patriarchal society (barring a few regions in the South). In it, the head of the family, who is a male, is responsible for the well-being of all and is also "the" decision maker. Obviously, children who are born and bred in joint families have rules to adhere to along with prescribed codes of conduct. There is a code of conduct meant for each and every member of the household. For example, while females are bearers of offspring, their key responsibility is raising children, both their own and of others in the family, while also taking care of the kitchen. In earlier days, there used to be one kitchen in which food used to be cooked for many members. The males had to take care of errands outside the four walls 
of the home. This entailed farming, merchandising or running business.

Now, children in these families had their perspectives built on what they saw and what they heard. Furthermore, it was considered bad manners to speak when elders were in conversation. Obviously, it can be safely concluded that these traits had an impact on their overall personality. Resultantly, it can be inferred that children belonging to joint families were less expressive unless they belonged to the younger lot, where one could get away with whatever they said or did, on grounds of being the youngest.

However, the current trend of the Indian family scenario centers on the nuclear pattern. Furthermore, as compared to earlier times, around a decade back, a nuclear family consisted of the mother, father and two kids. Today, however, the nuclear family comprises of the mother, the father and single child. In addition to this, with the rise in urban cities and metros, there also happens to be a rise in the number of divorces which results in a higher number of single parents. Resultantly, this new structure is giving rise to a generation which has a different way of processing information and expressing it. This can majorly be contributed to the rise of social media and the ever-increasing usage of cell phones, embedded with a plethora of apps. Ideally, if children today above the age of 25are able to express themselves freely, both on-line and off-line, they should be more expressive in terms of personality. In addition to the family, there are external factors may influence expressiveness in an individual. These include demographic and socioeconomic factors. The aim of this paper is to identifythe factors which affect youngsters and draw attention to factors affecting expressiveness therein. Thereafter, the paper proposes a predictive model of expressiveness.

\section{METHODOLOGY}

For this research, a Google document with close-ended questions was shared with students belonging to five Institutes in Uttar Pradesh and Mumbai. There was a total of 220 respondents for the same. All the respondents had filled the questionnaire in totality. Therefore, there were no invalid responses.
The questionnaire focused on various parameters in order to understand factors affecting expressiveness. It was divided into three sections, wherein the first section focused on basic information which included the individual's age, gender, background, level of education, medium of education, religion, community and the number of close friends.

The second portion of the questionnaire aimed at understanding the individual's family background. Questions in this section focused on the annual income in the family, the occupation of the father and his highest degree, the occupation of the mother and her highest degree, the family composition and number of siblings.

The third and final section was based on expressiveness of the individual based on selfperception, on a Likert scale of five wherein one was the least and five, the maximum. The respondent stated whether he/ she is able to express views freely in front of a stranger, is comfortable discussing sensitive issues with parents, friends and members of the opposite gender, the level of expressiveness on social/ digital platforms, on a one-to-one level, level expressiveness in front of the mother and before an audience which is biased and whether the individual thinks of himself/ herself as an introvert or an extrovert. There were only two questions in this section which were based on a simple "yes" or "no." The questions were; whether or not the person has been a) sexually harassed or b) bullied in their lifetime.

\section{RESULTS AND DISCUSSION}

On the basis of the above questionnaire, results of all 220 respondents were run through SPSS. In addition to this, regression was applied on certain factors.

Furthermore, the advanced phase of the research is based on identifying some of the factors which might affect the degree of expression in an individual using predictive tools on SPSS software.

Regression technique is used on the said data where the degree of expression is taken as a dependent variable and a linear model has been created using the various other factors, like age, location, gender, income etc., as the 
independent variables. The following equation is proposed;

$$
E=\beta_{0}+\beta_{1} x_{1}+\beta_{2} x_{2}+\beta_{3} x_{3}+\cdots+\beta_{n} x_{n}+e
$$

The above-mentioned equation tries to make a linear model which is able to predict the factors affecting Expression / Expressiveness of an individual. Where ' $E$ ' stands for the level or degree of Expression of an individual. ' $\beta_{0}$ ' is the constant, ' $\beta_{1}$ ' is the unstandardized coefficient for the factor ' $x_{1}$.' Similarly, ' $\beta_{2}$ ' is the unstandardized coefficient for the factor ' $x_{2}$.' Progressively, ' $\beta_{\mathrm{n}}$ ' is the unstandardized coefficient of the ' $n_{\text {th }}$ ' factor $\left(x_{n}\right)$ is taken into consideration.

At first, dummy variables were created for the categorical variables (Annexure A). Thereafter, the Descriptive Statistics of the data was listed. It is as follows;

The Descriptive statistics gives us the following information;

Majority of the respondents belong to an age group of 18-22 followed by 22-25, are males, belong to an urban setting, are well educated ( $45 \%$ postgraduates, $34 \%$ graduates), and are educated in the English medium. 55\% of the respondents have been educated in a Convent School (92\%). Around 43\% respondents have
2-5 close friends. The major chunk of respondents belongs to below 5 lakh annual income group (35\%), 5-8 lakh annual income group $(28.18 \%) .52 \%$ of the participants have their fathers working in a salaried job. However, when it comes to mothers, $85 \%$ of the respondents have their mothers as HomeMakers. The majority of responders have their father's highest educational qualification as graduates (53\%) and so is it the case with Mother's highest education (47\%). It is strange that majority of the mothers who are well educated in the Indian subcontinent prefer giving huge importance to their roles as a homemaker in the family and they give up their careers and other ambitions.

Most of the respondents have been bred in a nuclear family setting. Majority of the respondents have 1-2 siblings, have neither been bullied in their lives, nor have faced any form of harassment. In addition to this, majority of the respondents seem comfortable in expressing themselves, apart from discussing the sensitive issues like sexual life, puberty and periods with their parents, where the mean is relatively low (3.07).

The $\mathrm{R}$ square and Adjusted $\mathrm{R}$ square values are 0.415 and 0.280 , respectively. The Durbin Watson is 2.117 signifying the absence of autocorrelation in the residuals.

Descriptive Statistics

\begin{tabular}{|l|c|c|c|}
\hline & Mean & $\begin{array}{c}\text { Std. } \\
\text { Deviation }\end{array}$ & $\mathrm{N}$ \\
\hline Do you consider yourself as an ExtrovertorIntrovert & 3.17 & 1.104 & 220 \\
\hline I am able to expressmyviewsfreelyinfrontofastranger & 3.16 & 1.161 & 220 \\
\hline IamcomfortablediscussingsensitiveissueslikePeriod/ Puberty & 3.07 & 1.346 & 220 \\
\hline IcanfreelydiscusssensitiveissueslikePeriod / Pubertyissues & 3.81 & 1.209 & 220 \\
\hline Iaminclinedtoexpressmyselffreelyonadigitalplatform & 3.37 & 1.193 & 220 \\
\hline Iamcomfortableinexpressingthesameideas in person & 3.83 & 1.035 & 220 \\
\hline Iamcomfortableinopeninguporspeakingmymindinfront of others & 3.88 & 1.015 & 220 \\
\hline IamabletoexpressmyselfbetterinmyMotherTongue & 4.03 & 1.040 & 220 \\
\hline IamunabletoexpressmyselfbecauseIthink about others & 2.69 & 1.149 & 220 \\
\hline IamcomfortablehavingconversationswithmyFamilyregarding sensitive & 3.57 & 1.205 & 220 \\
\hline issues & & & \\
\hline Age=18-22 & .4318 & .49646 & 220 \\
\hline Age=22-25 & .3409 & .47510 & 220 \\
\hline Age=Above 25 & .2000 & .40091 & 220 \\
\hline Age=Below 18 & .0273 & .16325 & 220 \\
\hline Gender=Female & .3227 & .46859 & 220 \\
\hline Gender=Male & .6773 & .46859 & 220 \\
\hline Whichtypeofplacedoyoubelongto=Metro & .2682 & .44402 & 220 \\
\hline Whichtypeofplacedoyoubelongto=Rural & .1182 & .32356 & 220 \\
\hline
\end{tabular}




\begin{tabular}{|c|c|c|c|}
\hline & Mean & \begin{tabular}{c|} 
Std. \\
Deviation
\end{tabular} & $\mathrm{N}$ \\
\hline Whichtypeofplacedoyoubelongto=Urban & .6136 & .48803 & 220 \\
\hline WhatisthehighestlevelofEducationattainedbyyou=Graduate & .3409 & .47510 & 220 \\
\hline WhatisthehighestlevelofEducationattainedbyyou=High School & .2091 & .40759 & 220 \\
\hline WhatisthehighestlevelofEducationattainedbyyou=Postgraduate & .4500 & .49863 & 220 \\
\hline WhathasbeenthemediumofEducationpursuedbyyou=English Medium & .9273 & .26028 & 220 \\
\hline WhathasbeenthemediumofEducationpursuedbyyou=Hindi Medium & .0727 & .26028 & 220 \\
\hline HaveyoueverbeeneducatedinaConventSchool=No & .4500 & .49863 & 220 \\
\hline HaveyoueverbeeneducatedinaConventSchool=Yes & .5500 & .49863 & 220 \\
\hline Howmanyclosefriendsdoyouhavewhomyoucanconfidein $=0-2$ & .3455 & .47660 & 220 \\
\hline Howmanyclosefriendsdoyouhavewhomyoucanconfidein & .4364 & .49706 & 220 \\
\hline $\begin{array}{l}\text { Howmanyclosefriendsdoyouhavewhomyoucanconfidein =More than } \\
5\end{array}$ & .2182 & .41395 & 220 \\
\hline Whatisyourannualhouseholdincome=5-8 lakh p.a. & .2818 & .45091 & 220 \\
\hline Whatisyourannualhouseholdincome=8-10 lakh p.a. & .1318 & .33906 & 220 \\
\hline Whatisyourannualhouseholdincome=Above 10 lakh p.a. & .2318 & .42296 & 220 \\
\hline Whatisyourannualhouseholdincome $=$ Below 5 lakh p.a. & .3545 & .47947 & 220 \\
\hline $\begin{array}{l}\text { WhatistheoccupationofyourFather=Businessman } \\
\text { (Shops/Restaurant/Factory/Plant/Other Family Businesses etc) }\end{array}$ & .3955 & .49006 & 220 \\
\hline $\begin{array}{l}\text { WhatistheoccupationofyourFather=Salaried (Banks/State Services/ } \\
\text { Central Government/RBI/Police/Professor/Bureaucrat/Corporate/ } \\
\text { Private etc) }\end{array}$ & .5273 & .50039 & 220 \\
\hline $\begin{array}{l}\text { WhatistheoccupationofyourFather=Self } \\
\text { (Engineer/Doctor/Chartered Accountant/Free Lancer/ etc) }\end{array}$ & .0773 & .26763 & 220 \\
\hline $\begin{array}{l}\text { WhatistheoccupationofyourMother=Businesswoman } \\
\text { (Shops/Restaurant/Factory/Plant/Other Family Businesses etc) }\end{array}$ & .0182 & .13391 & 220 \\
\hline WhatistheoccupationofyourMother=Homemaker & .8545 & .35336 & 220 \\
\hline $\begin{array}{l}\text { WhatistheoccupationofyourMother=Salaried (Banks/State Services/ } \\
\text { Central Government/RBI/Police/Professor/Bureaucrat/Corporate/ } \\
\text { Private etc) }\end{array}$ & .1045 & .30666 & 220 \\
\hline $\begin{array}{l}\begin{array}{l}\text { WhatistheoccupationofyourMother=Self } \\
\text { (Engineer/Doctor/Chartered Accountant/Free Lancer/ etc) }\end{array} \\
\end{array}$ & .0227 & .14937 & 220 \\
\hline WhatisthehighestEducationofyourFather=Graduate & .5364 & .49981 & 220 \\
\hline WhatisthehighestEducationofyourFather=High School & .1818 & .38657 & 220 \\
\hline WhatisthehighestEducation ofyourFather=Phd & .0182 & .13391 & 220 \\
\hline WhatisthehighestEducationofyourFather=Postgraduate & .1682 & .37488 & 220 \\
\hline $\begin{array}{l}\text { WhatisthehighestEducationofyourFather=Professional } \\
\text { (Engineering/MBBS/MS/CA/MCA/MBA etc) }\end{array}$ & .0955 & .29451 & 220 \\
\hline WhatisthehighestEducationofyourMother=Graduate & .4727 & .50039 & 220 \\
\hline WhatisthehighestEducationofyourMother=High School & .2955 & .45729 & 220 \\
\hline WhatisthehighestEducationofyourMother=Phd & .0136 & .11624 & 220 \\
\hline WhatisthehighestEducationofyourMother=Postgraduate & .2182 & .41395 & 220 \\
\hline WhattypeofFamilyCompositiondoyoubelongto=Joint Family & .3455 & .47660 & 220 \\
\hline WhattypeofFamilyCompositiondoyoubelongto=Nuclear Family & .6545 & .47660 & 220 \\
\hline HowmanySiblingsdoyouhave $=1-2$ & .6727 & .47029 & 220 \\
\hline HowmanySiblingsdoyouhave=More than 2 & .2136 & .41081 & 220 \\
\hline $\begin{array}{l}\text { HowmanySiblingsdoyouhave=None (you are the single child of your } \\
\text { parents) }\end{array}$ & .1136 & .31809 & 220 \\
\hline HaveyoueverfacedanyformofharassmentinyourlifeSexual=No & .6000 & .49102 & 220 \\
\hline HaveyoueverfacedanyformofharassmentinyourlifeSexual=Yes & .4000 & .49102 & 220 \\
\hline WereyoueverbulliedbyanyoneduringyourSchoolorCollegedays=No & .6273 & .48463 & 220 \\
\hline WereyoueverbulliedbyanyoneduringyourSchoolorCollegedays=Yes & .3727 & .48463 & 220 \\
\hline
\end{tabular}


Excluded Variables $^{2}$

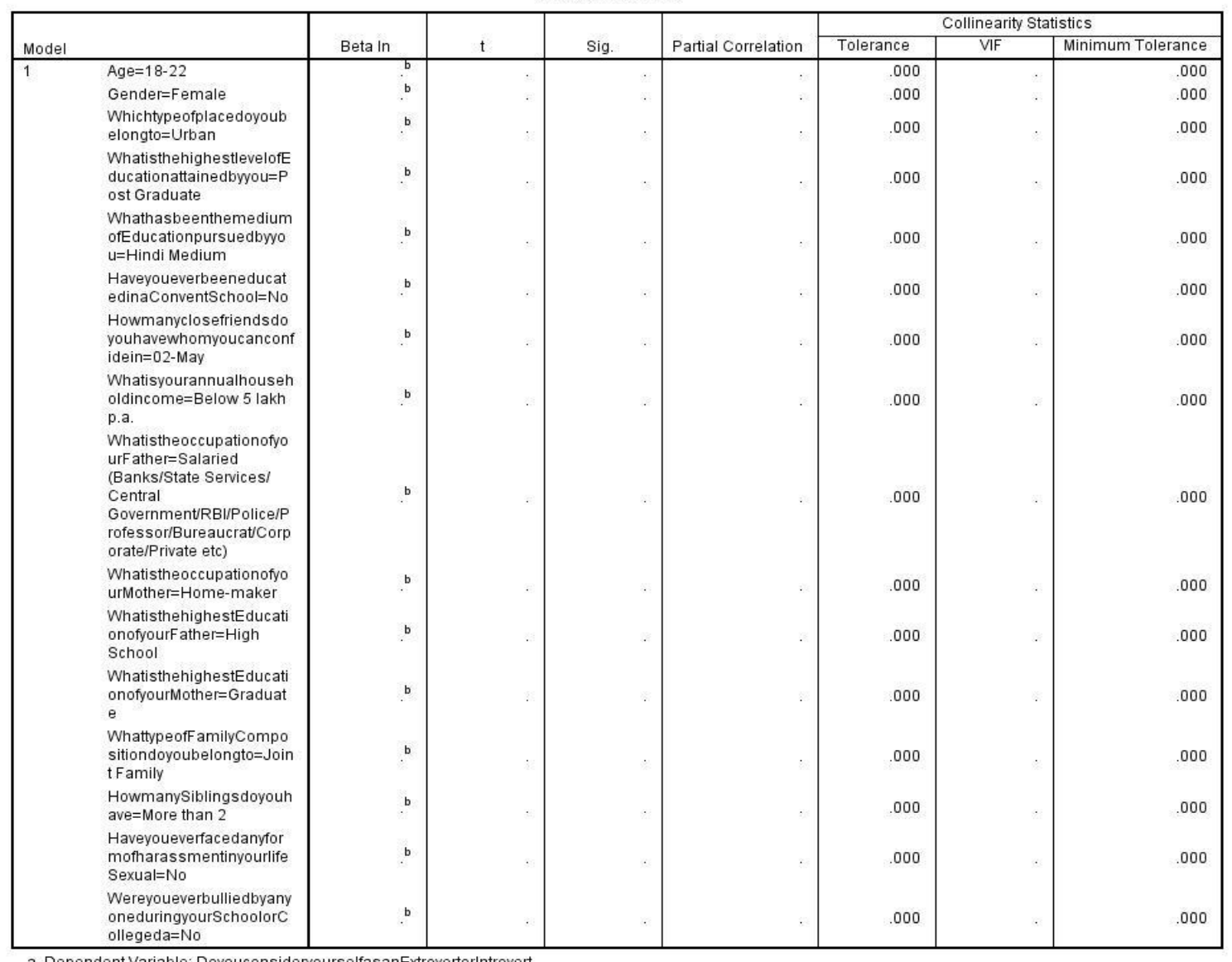

a. Dependent Variable: DoyouconsideryourselfasanExtrovertorintrovert

b. Predictors in the Model: (Constant), WereyoueverbulliedbyanyoneduringyourSchoolorCollegeda=Yes, lamunabletoexpressmyselfbecauselthinkthatothersAudien, lamabletoexpressmyselfbetterinmyMotherTongue, HaveyoueverbeeneducatedinaConventSchool=Yes,

lamcomfortablediscussingsensitiveissueslikePeriodPuberty, WhatisthehighestEducationofyourMother=Post Graduate,

WhatistheoccupationofyourMother=Businessman (Shops/Restaurant/Factory/Plant/Other Family Businesses etc). Age=Below 18

Howmanyclosefriends doyouhavewhomyoucanconfidein=More than 5 , WhatisthehighestlevelofEducationattainedbyou=Graduate,

WhatisthehighestEducation ofyourF ather $=$ Graduate, HowmanySiblingsdoyouhave $=01-\mathrm{Feb}$, Whatisyourannualhouseholdincome $=5-8$ lakh p.a.,

WhatistheoccupationofyourF ather=Self Employed (Engineer/Doctor/Chartered Accountant/Free Lancer/ etc), WhatisthehighestEducationofyourF ather=Phd, WhattypeofF amilyCompositiondoyoubelongto=Nuclear Family, Gender=Male, Whichtypeofplacedoyoubelongto=Metro, WhatistheoccupationofyourMother=Self Employed (Engineer/Doctor/Chartered Accountant/Free Lancer/ etc), Whatisyourannualhouseholdincome $=8-10$ lakh p.a., Age=22-25,

laminclinedtoexpressmyselffreelyonadigitalplatformlik, WhathasbeenthemediumofEducationpursuedbyyou=English Medium,

WhatistheoccupationofyourMother=Salaried (Banks/State Services/Central Government/RBI/Police/Professor/Bureaucrat/Corporate/Private etc),

lamabletoexpressmywiewsfreelyinfrontofastranger, Howmanyclosefriendsdoyouhavewhomyoucanconfidein $=0-2$, WhatisthehighestEducationofyourMother=Phd, WhatisthehighestEducationofyourF ather=Professional Course (Engineering/MBBS/MS/CA/MCA/MBA etc),

HaveyoueverfacedanyformofharassmentinyourlifeSexual=Yes, WhatistheoccupationofyourF ather=Businessman (Shops/Restaurant/Factory/Plant/Other Family Businesses etc), Whichtypeofplacedoyoubelongto=Rural, lamcomfortableinopeninguporspeakingmymindinfrontoft, Whatisyourannualhouseholdincome=Above 10 lakh p.a., HowmanySiblingsdoyouhave=None (you are the single child of your parents), lamcomfortablehavingconversationswithmyF amilyregardingi,

IcanfreelydiscusssensitiveissueslikePeriodPubertyissues, WhatisthehighestEducationofyourMother=High School,

WhatisthehighestlevelofEducationattainedbyyou=High School, lamcomfortableinexpressingthesameideasWhichicanexpre, Age=Above 25,

WhatisthehighestEducationofyourF ather=Post Graduate

\begin{tabular}{|c|c|c|c|c|c|c|c|c|c|c|}
\hline \multicolumn{11}{|c|}{ Model Summary ${ }^{\mathbf{b}}$} \\
\hline \multirow[b]{2}{*}{ Model } & \multirow[b]{2}{*}{$\mathrm{R}$} & \multirow[b]{2}{*}{$R$ Square } & \multirow[b]{2}{*}{$\begin{array}{l}\text { Adjusted R } \\
\text { Square }\end{array}$} & \multirow[b]{2}{*}{$\begin{array}{l}\text { Std. Error of } \\
\text { the Estimate }\end{array}$} & \multicolumn{5}{|c|}{ Change Statistics } & \multirow[b]{2}{*}{$\begin{array}{l}\text { Durbin- } \\
\text { Watson }\end{array}$} \\
\hline & & & & & $\begin{array}{l}\text { R Square } \\
\text { Change }\end{array}$ & F Change & $\mathrm{df1}$ & $\mathrm{df} 2$ & Sig. F Change & \\
\hline 1 & $.644^{\mathrm{a}}$ & .415 & .280 & .936 & .415 & 3.079 & 41 & 178 & .000 & 2.117 \\
\hline
\end{tabular}

a. Predictors: (Constant), Wereyoueverbullied byanyoneduringyourSchoolorCollegeda $=$ Yes, lamunabletoexpressmyselfbecauselthinkthatothersAudien, lamabletoexpressmyselfbetterinmyMotherTongue, HaveyoueverbeeneducatedinaConvent 5 chool=Yes,

Whates , Age = Below 18 ,

WhatisthehighestEducationofyourFather $=$ Graduate, HowmanySiblingsdoyouhave $=01-\mathrm{Feb}$, Whatisyourannual household income $=5-8$ lakh $\mathrm{p}$.

Whatistheoccupation fyourFather=Self Employed (Engineer/Dor /Chartered Accountant/Free Lancer/ toc),

WhatisthehighestEducationofyourFather=Phd, WhattypeofFamilyCompositiond oyoubelongto=Nuclear Family, Gender=Male,

Whichtypeofplaced oyoubelongto=Metro, WhatistheoccupationofyourMother=Self Employed (Engineer/Doctor/Chartered Accountant/Free Lancer/ etc), Whatisyourannualhouseholdincome $=8-10$ lakh p.a., Age $=22-25$, laminclinedtoexpressmyselffreelyonadigitalplatformlik,

etc), Whatisyourannualhouseholdincome $=8-10$ lakh p.a., Age $=22-25$, laminclinedtoexpressmyselffreelyonadigitalplatformlik, WhathasbeenthemediumofEducationpursuedbyyou=English Medium, WhatistheoccupationofyourMother=Salaried (Banks/S
Government/RBI/Police/Professor/Bureaucrat/Corporate/Private etc), lamabletoexpressmyviewsfreelyinfrontofastranger,

Government/RB/Police/Professor/Bureaucrat/Corporate/Private etc), lamabletoexpressmyviewsfreelyinfron

WhatisthehighestEducationofyourFather=Professional Course (Engineering/MBBS/MS/CA/MCA/MBA etc),

HaveyoueverfacedanyformofharassmentinyourlifeSexual=Yes, WhatistheoccupationofyourFather $=$ Businessman

(Shops/Restaurant/Factory/Plant/Other Family Businesses etc), Whichtypeofplacedoyoubelongto=Rural,

lamcomfortableinopeninguporspeakingmymind infrontoft, Whatisyourannualhouseholdincome =Above 10 lakh p.a.,

HowmanySiblingsdoyouhave = None (you are the single child of your parents), lamcomfortablehavingconversationswithmyFamilyregardingi, IcanfreelydiscusssensitiveissueslikePeriodPubertyissues, WhatisthehighestEducationofyourMother=High School,

WhatisthehighestlevelofEducationattained byyou=High School, lamcomfortableinexpressingthesameideasWhichicanexpre, Age=Above 25 , WhatisthehighestEducationofyourFather=Post Graduate 
ANOVA $^{\mathrm{a}}$

\begin{tabular}{|c|c|c|c|c|c|c|}
\hline Model & & $\begin{array}{l}\text { Sum of } \\
\text { Squares }\end{array}$ & df & Mean Square & $\mathrm{F}$ & Sig. \\
\hline \multirow[t]{3}{*}{1} & Regression & 110.701 & 41 & 2.700 & 3.079 & $.000^{\mathrm{b}}$ \\
\hline & Residual & 156.076 & 178 & .877 & & \\
\hline & Total & 266.777 & 219 & & & \\
\hline
\end{tabular}

a. Dependent Variable: DoyouconsideryourselfasanExtrovertorintrovert

b. Predictors: (Constant),

Wereyoueverbullied byanyoneduringyourSchoolorCollegeda $=$ Yes,

lamunabletoexpressmyselfbecauselthinkthatothersAudien,

lamabletoexpressmyselfbetterinmyMotherTongue,

HaveyoueverbeeneducatedinaConventSchool=Yes,

lamcomfortablediscussingsensitiveissueslikePeriodPuberty,

WhatisthehighestEducationofyourMother=Post Graduate,

WhatistheoccupationofyourMother $=$ Businessman

(Shops/Restaurant/Factory/Plant/Other Family Businesses etc), Age=Below 18,

Howmanyclosefriendsdoyouhavewhomyoucanconfidein=More than 5 ,

WhatisthehighestlevelofEducationattained byyou $=$ Graduate,

WhatisthehighestEducationofyourFather $=$ Graduate,

HowmanySiblingsdoyouhave $=01-\mathrm{Feb}$, Whatisyourannualhouseholdincome $=5-8 \mathrm{lakh}$

p.a., WhatistheoccupationofyourFather =Self Employed (Engineer/Doctor/Chartered

Accountant/Free Lancer/ etc), WhatisthehighestEducationofyourFather=Phd,

WhattypeofFamilyCompositiond oyoubelongto=Nuclear Family, Gender $=$ Male,

Whichtypeofplacedoyoubelongto=Metro, WhatistheoccupationofyourMother=Self

Employed (Engineer/Doctor/Chartered Accountant/Free Lancer/ etc),

Whatisyourannualhouseholdincome $=8-10$ lakh p.a., Age $=22-25$,

laminclinedtoexpressmyselffreelyonadigitalplatformlik,

WhathasbeenthemediumofEducationpursued byyou=English Medium,

WhatistheoccupationofyourMother=Salaried (Banks/State Services/Central

Government/RBI/Police/Professor/Bureaucrat/Corporate/Private etc),

lamabletoexpressmyviewsfreelyinfrontofastranger,

Howmanyclosefriendsdoyouhavewhomyoucanconfidein $=0-2$,

WhatisthehighestEducationofyourMother $=$ Phd,

WhatisthehighestEducationofyourFather=Professional Course

(Engineering/MBBS/MS/CA/MCA/MBA etc),

HaveyoueverfacedanyformofharassmentinyourlifeSexual=Yes,

WhatistheoccupationofyourFather $=$ Businessman

(Shops/Restaurant/Factory/Plant/Other Family Businesses etc),

Whichtypeofplacedoyoubelongto= Rural,

lamcomfortableinopeninguporspeakingmymindinfrontoft,

Whatisyourannualhouseholdincome=Above 10 lakh p.a.,

HowmanySiblingsdoyouhave=None (you are the single child of your parents),

lamcomfortablehavingconversationswithmyFamilyregardingi,

IcanfreelydiscusssensitiveissueslikePeriodPubertyissues,

WhatisthehighestEducationofyourMother=High School,

WhatisthehighestlevelofEducationattained byou=High School,

lamcomfortableinexpressingthesameideasWhichicanexpre, Age=Above 25,

WhatisthehighestEducationofyourFather $=$ Post Graduate

There are some variables which have been exclued from the analysis with the tolerance = 0 , since these variables can be perfectly predicted from one or the other independent variables. These variables are listed in the excluded variables table below and are as follows; 


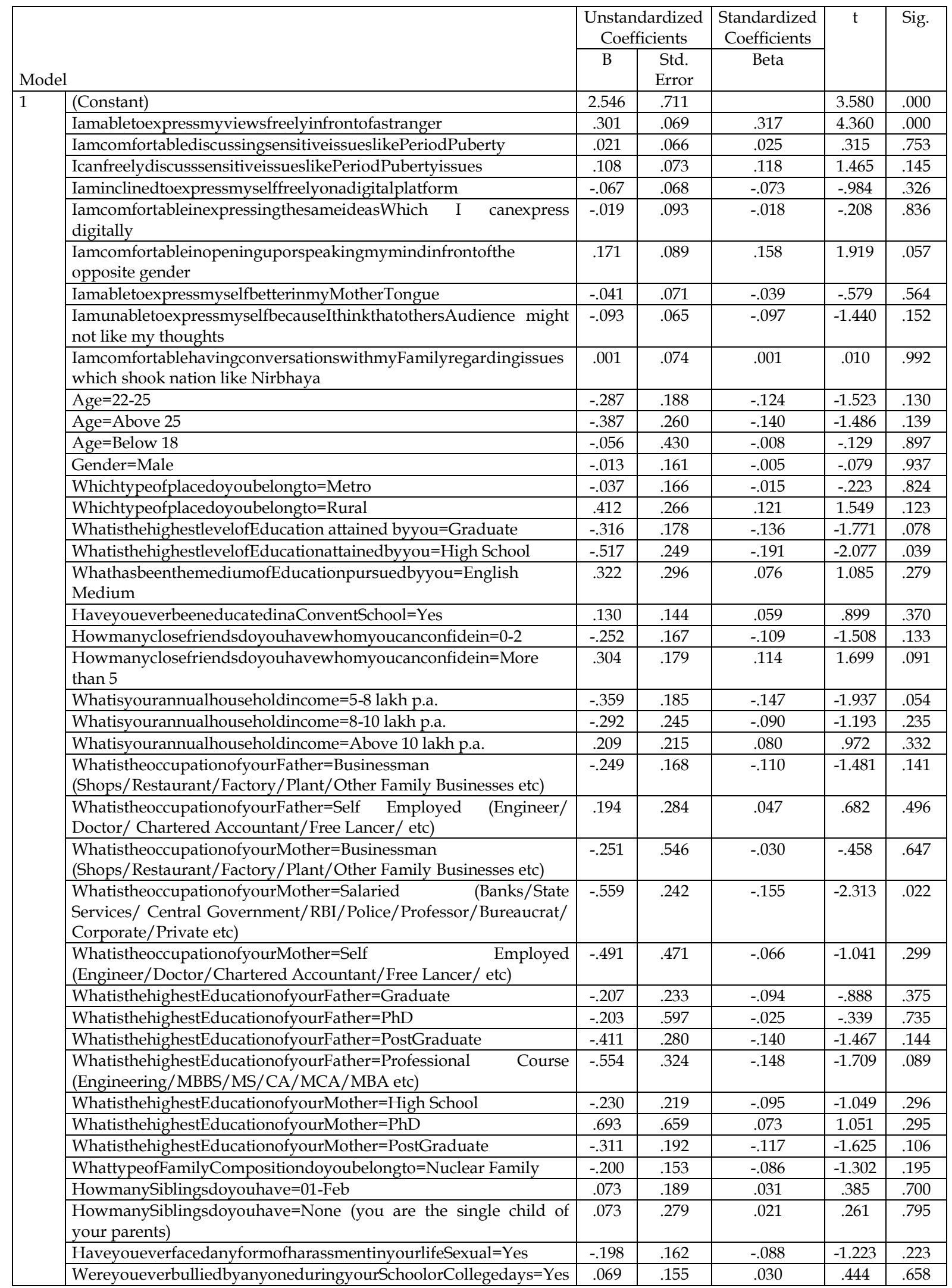

With reference to the results above and research questions framed in the Introduction section, we have the followingoutputs:
$\mathrm{RQ}_{1}$ : Does age of an Individual affect his/her expressive behavior? No

$\mathrm{RQ}_{2}$ : Is one better able to express oneself in his/her mother tongue? No 
$\mathrm{RQ}_{3}$ : Does one's gender affect the expressive behavior of an individual? No

$\mathrm{RQ}_{4}$ : Does the type of place one belongs to affect the expressive behavior of an individual? No

$\mathrm{RQ}_{5}$ : Does the medium of Education affect the degree of expressiveness in a person? No

$\mathrm{RQ}_{6}$ : Does Convent Education affect the expressive behavior of a person? No

$\mathrm{RQ}_{7}$ : Does Family Composition affect the expressive behavior in an individual? No

$\mathrm{RQ}_{8}$ : Do the number of siblings affect the degree of expressiveness in a person? No

$\mathrm{RQ}_{9}$ : Does the education level affect the level of expressiveness? Yes

$R Q_{10}$ : Does openness to the opposite gender affect expressiveness? Yes

$R Q$ 11: Do the Number of friends influence Expressiveness? Yes

RQ 12: Does family income affect expressiveness? Yes

$R Q_{13:}$ Does the education level of parents have an effect on expressiveness? Yes

$R Q$ 14: Can articulating in front of a stranger have an impact on expressiveness? Yes

That is to say, contrary to many myths and beliefs, demographic factors, the mother tongue, etc. do not affect the expressiveness of an individual. The predictive model does not consider these factors as significant. Furthermore, considering the significance of ' $\alpha$ ' to the level of $10 \%$ or 0.10 , the following factors are significant;

1. Whether an individual is able to express himself in front of a stranger.

2. If an individual is comfortable in opening up or speaking his/ her mind in front of the opposite gender.

3. Where the highest Educational qualification is Graduation.

4. Where the highest Educational qualification is High School.

5. People who have more than 5 friends in whom one can confide in.

6. People with household family income between 5-8 lakhs per annum.

7. Where the Mother is employed in a salaried job.

8. Where the father has highest Education as a professional course like Engineering/ MBBS/CA/MBA etc.

On taking into account the coefficients of factors which have shown significance through analysis, we have the following output:

It can be seen that none of the coefficients are greater than 1 or less than -1 . This is suggestive that there are many factors which affect an individual's expressiveness, depending upon the various experiences which $\mathrm{s} /$ he might have faced in his/her life. This includes the type of surroundings where one has grown up during early childhood days. In addition to this, there are some factors which affect expressiveness such as the number of friends one has (which has a positive Coefficient of 0.304), expression in front of a stranger(0.301), expression in front of the opposite gender(0.171), Highest Educational Qualification of Graduate(-0.316) and High School(-0.517), Household income between 5-8 lakhs p.a.(-0.359), Mother is employed in a salaried job(-0.559) and Highest education of father is a Professional degree course like Engineering/MBBS/CA/MBA etc. $(-0.554)$

\section{CONCLUSION/ IMPLICATIONS}

Based on the above results, points which can be concluded from the predictive model of expressiveness are as follows;

i) Friendship is definitely a strong bond which boosts expressive in an individual. Friendship is also one of the pillars of Social Development since it gives more emphasis to relationships which a person makes during one's lifetime rather than the relationships with which one is born with. Having said this, the first friend which a person gets during the journey of life is one's sibling. It is often seen that siblings develop a better bond between themselves which leads to better expression in an individual. This is also proved by the model where the highest Coefficient of 0.545 has been given to the number of siblings. The number of siblings is positively and directly proportional in the Model.

ii) Expressing one's views in front of a stranger makes an individual more confident. In this highly competitive world, it is necessary to convey the right meaning to the right person without any ambiguity. Therefore, Schools, Colleges, Managerial Institutes and Universities should lay more emphasis on speaking in front of a crowd. This can be done by 
building a robust curriculum which focusses on activities that promote expressiveness. At Jaipuria Institute of Management, presentations are encouraged in front of peer groups through project presentations. This forms a valuable part of the final assessment of a student throughout the program. It can be advised to the Ministry of Human Resource and Development, Government of India, to replicate this Model throughout the country in order to make India a Service Exporter to the World and also a Skilled Manpower exporter.

iii) It is also observed that the social structure in the country doesn't allow students of opposite genders to intermingle. This is specifically true in Tier II and Tier III cities. This has huge impact on the expressive behaviour of an individual. The participation of women in higher education needs to be boosted. This factor has a positive impact on the degree of expressiveness, as is shown in the results.. In general, with reference to the SDGs, huge emphasis should be laid upon on the education and participation of females in the workforce of the country.

\section{LIMITATIONS AND SCOPE OF FUTURE STUDY}

Since the sample size was not big enough to study the influence of factors affecting expressiveness based on geography that is, state-wise, further studies may be conducted to analyse the same. A greater geographical area would aid in understanding the impact of socio-cultural and religious factors on expressiveness. The above findings are preliminary which can be explored in depth and be validated. The idea is to understand the impact of demography, socio-economics and the family on the expressive behaviour ofan individual.In addition to this, the behaviour of an individual is shaped by many factors which are difficult to quantify objectively. Hence, predicting the exact behaviour might be difficult with the present technical expertise but maybe in future, humanity may reach the technical zenith to do so.

Annexure A

Variable Creation

\begin{tabular}{|l|l|}
\hline & Label \\
\hline Age_1 & Age=18-22 \\
Age_2 & Age=22-25 \\
Age_3 & Age=Above 25 \\
Age_4 & Age=Below 18 \\
Gender_5 & Gender=Female \\
Gender_6 & Gender=Male \\
Place_7 & Which type of place do you belong to=Metro \\
Place_8 & Which type of place do you belong to=Rural \\
Place_9 & Which type of place do you belong to=Urban \\
EducationLevel_10 & What is the highest level of Education attained by you=Graduate \\
EducationLevel_11 & What is the highest level of Education attained by you=High School \\
EducationLevel_12 & What is the highest level of Education attained by you=Post Graduate \\
EducationMedium_13 & What has been the medium of Education pursued by you=English Medium \\
EducationMedium_14 & What has been the medium of Education pursued by you=Hindi Medium \\
ConventEdu_15 & Have you ever been educated in a Convent School=No \\
ConventEdu_16 & Have you ever been educated in a Convent School=Yes \\
CloseFriends_17 & How many close friends do you have whom you can confide in=0-2 \\
CloseFriends_18 & How many close friends do you have whom you can confide in=2-5 \\
CloseFriends_19 & How many close friends do you have whom you can confide in=More than \\
& 5 \\
Income_20 & What is your annual house hold income=5-8 lakh p.a. \\
Income_21 & What is your annual house hold income=8-10 lakh p.a. \\
Income_22 & What is your annual house-hold income=Above 10 lakh p.a. \\
Income_23 & What is your annual household income=Below 5 lakh p.a.
\end{tabular}




\begin{tabular}{|c|c|}
\hline FatherOccupation_24 & $\begin{array}{l}\text { What is the occupation of your Father=Businessman } \\
\text { (Shops/Restaurant/Factorv/Plant/Other Family Businesses etc) }\end{array}$ \\
\hline FatherOccupation_25 & $\begin{array}{l}\text { What is the occupation of your Father=Salaried (Banks/State Services/ } \\
\text { Central Government/RBI/Police/Professor/Bureaucrat/Corporate/Private } \\
\text { etc) }\end{array}$ \\
\hline FatherOccupation_26 & $\begin{array}{l}\text { What is the occupation of your Father=Self Employed } \\
\text { (Engineer/Doctor/Chartered Accountant/Free Lancer/ etc) }\end{array}$ \\
\hline MotherOccupation_27 & $\begin{array}{l}\text { What is the occupation of your Mother=Businessman } \\
\text { (Shops/Restaurant/Factory/Plant/Other Family Businesses etc) }\end{array}$ \\
\hline MotherOccupation_28 & What is the occupation of your Mother=Home-maker \\
\hline MotherOccupation_29 & $\begin{array}{l}\text { What is the occupation of your Mother=Salaried (Banks/State Services/ } \\
\text { Central Government/RBI/Police/Professor/Bureaucrat/Corporate/Private } \\
\text { etc) }\end{array}$ \\
\hline MotherOccupation_30 & $\begin{array}{l}\text { What is the occupation of your Mother=Self Employed } \\
\text { (Engineer/Doctor/Chartered Accountant/Free Lancer/ etc) }\end{array}$ \\
\hline FatherEducation_31 & What is the highest Education of your Father=Graduate \\
\hline ication_32 & What is the highest Education of your Father=High School \\
\hline $\mathrm{Fa}$ & What is the highest Education of your Father $=\mathrm{PhD}$ \\
\hline $\mathrm{Fa}$ & What is the highest Education of your Father $=$ PostGraduate \\
\hline Ication_35 & $\begin{array}{l}\text { What is the highest Education of your Father=Professional Course } \\
\text { (Engineering/MBBS/MS/CA/MCA/MBA etc.) }\end{array}$ \\
\hline MotherEducati & What is the highest Education of your Mother $=$ Graduate \\
\hline 7 & of your Mother=High School \\
\hline 8 & What is the highest Educat \\
\hline MotherEducation & our Mother=PostGraduate \\
\hline 40 & do you belong to $=$ \\
\hline 1 & do you belong to=Nuclear Family \\
\hline 42 & -2 \\
\hline No & How many Siblings do you have=More than 2 \\
\hline NoOfSiblings_44 & $\begin{array}{l}\text { How many Siblings do you have }=\text { None (you are the single child of your } \\
\text { parents) }\end{array}$ \\
\hline Harassment_45 & Have you ever faced any form of harassment in your life Sexual=No \\
\hline ment_46 & Have you ever faced any form of harassment in your life Sexual=Yes \\
\hline & Were you ever bullied by anyone during your School or College days \\
\hline Bullying_48 & ere you ever bullied by anyone during your School or College days=Yes \\
\hline
\end{tabular}

\section{REFERENCES}

Arjun S and Rai S (2018) Crime by the Commons, Emerging Trend in Social Media, Journal of Content, Community \& Communication, Amity School of Communication Vol. 8, Year 4.

Chadda RK, Deb KS (2013),Indian family systems, collectivistic society and psychotherapy,.Indian J Psychiatry. Jan;55(Suppl 2):S299-309. doi: 10.4103/00195545.105555 .

Edelberg,G. S. (2006). De Introvertidos $Y$ Extravertidos, Debates IESA, 11(4), 8-9. Retrieved from

http://search.ebscohost.com/login.aspx?direc

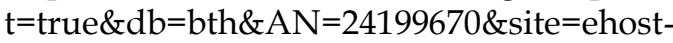
live
Eysenck H J and Eysenck S B G (1963), The

Eysenck Personality Inventory, p. 369,

Educational and Industrial Testing Service,

San Diego, California.

Filer R K (1986), The Role of Personality and Tastes in Determining Occupational Structure, Industrial and Labor Relations Review, Vol. 39, No. 3, pp. 412-424.

Heckmann, J. J. (2014, December 15), The White House summit on early education, Retrieved from http://heckmanequation.org/ content/white-house-summit-early-education

Hui, C. and Triandis, H. (1985), Measurement in Cross-Cultural Psychology: A Review and Comparison of Strategies, Journal of CrossCultural Psychology, Vol. 16. 
Kozhina M.N. (1987), On Linguistic and Speech Expressiveness, its Extralinguistic Basis/ Problems of Expressive Syntax, Moscow.

Mangla S and Manisha (2019), Social Construction of Gender through Mediated Communication in India, Journal of Content, Community \& Communication, Amity School of Communication, Vol. 9 Year 5.

Mary Ann Liebert, Inc. (2002), On the Internet No One Knows I'm an Introvert: Extroversion, Neuroticism, and Internet Interaction, Cyberpsychology and Behaviour Volume 5, Number 2.

Ryscavage, P. (1993). Recent data on job prospects of college-educated youth. Monthly Labor Review, 116(8),16.Retrievedfrom http:/ / search.ebscohost.com/login.aspx?direc

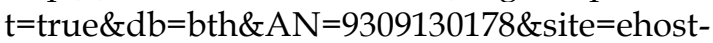
live

Winkler, S., König, C., \&Kleinmann, M. (2013), What makes human resource information successful? Managers' perceptions of attributes for successful human resource information, International Journal of Human Resource Management, 24(2), 227-242. https://doi.org/10.1080/09585192.2012.68006 8

Morris M and Massie P (1999), Cybercareers. Mountain View, CA, Sun Microsystems.

Kahnweiler, J. B. (2011), How to Manage an Extrovert When You're an Introvert,
Bloomberg.Com, 3. Retrieved from http://search.ebscohost.com/login.aspx?direc

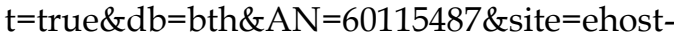
liveRadio's employment mix. (n.d.). Advertiser, The (Adelaide). Retrieved from http://search.ebscohost.com/login.aspx?direc

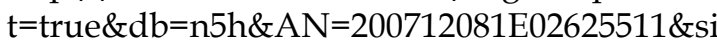
te $=$ ehost-live

Singh S (1994), Gender Differences in Work Values and Personality Characteristics Among Indian Executives, Journal of Social Psychology, Vol. 134, No. 5, pp. 699-700.

Super D E and Crites J O (1962), Appraising Vocational Fitness, Rev. Edition, Harper \& Brothers, New York.

Tett R P, Jackson D N and Rothstein M (1991), Personality Measures as Predictors of Job Performance: A Meta-Analytic Review, Personnel Psychology, Vol. 44, pp. 703-742.

Utpal V K Jha (2017), A Study on the Engagement of Indian Students on Social Media*, Journal of Content, Community \& Communication Amity School of Communication Vol. 6 Year 3, June - 2017.

Zeffane. R (2013), Need for Achievement, Personality and Entrepreneurial Potential: a Study Of Young Adults in the United Arab Emirates, Journal of Enterprising Culture, Vol. 21, No. 1, pp 75-105. 